\title{
Layoffs, Coping, and Commitment: Impact of Layoffs on Employees and Strategies Used in Coping with Layoffs
}

\author{
Sunil J. Ramlall ${ }^{1}$, Saleh Al-Sabaan ${ }^{2} \&$ Samia Magbool$^{2}$ \\ ${ }^{1}$ Graduate School, College of Business and Management, Cardinal Stritch University (Eden Prairie), Milwaukee, \\ Wisconsin, USA \\ ${ }^{2}$ Department of Business Administration, King Abdulaziz University, Jeddah, Saudi Arabia \\ Correspondence: Sunil J. Ramlall, Ph.D., Associate Professor, Graduate School, College of Business and Management, \\ Cardinal Stritch University (Eden Prairie), Milwaukee, Wisconsin, USA. Tel: 414-410-8827, 651-210-2761. E-mail: \\ sjramlall1@stritch.edu
}

Received: February 12, 2014

Accepted: April 8, 2014

Online Published: May 4, 2014

doi:10.5430/jms.v5n2p25

URL: http://dx.doi.org/10.5430/jms.v5n2p25

\begin{abstract}
Layoffs continue to plague organizations around the world especially as organizations attempt to optimize labor costs and other expenses. While there have been studies to attempt to understand the impact of layoffs, there are still gaps in the literature especially as we look at layoffs in the $21^{\text {st }}$ century. This research examined i) the impact of layoffs on individuals' psychological and physical well-being, ii) the impact of layoffs on the employees affective commitment, iii) coping strategies used by employees, and iv) job search strategies people are using to find new jobs. While, downsizing is a relatively common change management strategy that has been adopted for more than two decades, the prime impetus of most downsizing efforts is the desire for an immediate reduction of costs and simply survival.

We found that individuals will experience significant more health problems after being laid off from their jobs. Individuals who have been unemployed for longer periods will have lower affective commitment to their former employers. We also found that maintaining more control-oriented coping strategies will be more progressive in their job searches and more able to cope with layoffs and that coping strategies are positively related to reemployment. In addition, individuals who are receiving unemployment insurance and other benefits, financial hardships exist resulting in significant challenges and life style changes and coping strategies are positively related to financial resources available to an individual.
\end{abstract}

Keywords: employee layoffs, employee well-being, coping, job-search, rationale for layoffs, impact of layoffs

Although employee turnover has been studied since the turn of the century (Hom \& Griffeth, 1995) to the point where major conceptual models have been developed (e.g., March \& Simon, 1958; Mobley, Griffeth, Hand, \& Meglino, 1979; Price, 1977), the relevance of turnover is as significant as it has ever been. More recently there has been further significant contribution to the understanding of turnover (Cameron, 1994; Cameron, Freeman, \& Mishra, 1991; W. F. Cascio, 2005; De Meuse, Bergmann, Vanderheiden, \& Roraff, 2004; DeWitt, 1993; Zatzick \& Iverson, 2006). The significance is because of the fact that from December 2007 to November 2008, the number of unemployed persons in the United States has increased by 2.7 million, reflecting an increase of 1.7 percentage points (BLS, 2008). Both the number of unemployed persons, at 10.2 million, and the unemployment rate, at 6.6 percent, changed little in January, 2014 (BLS, 2014).

Empirical research and narrative reports from working managers suggest that employee attitudes can be negatively influenced by organizational downsizing (Kammeyer-Mueller \& Liao, 2006), but to what extent? Research that has been done on the downsizing process has focused on lay-off victims and has provided examples of family disintegration, collapse of social networks, and the decline of victims' physical and mental health among other negative side effects (Wang-Bae, 2003). With layoffs are typically financial constraints including foreclosures on one's house and other material possessions. Families are making radical changes to cope. Some survive; some don't.

Given this reality, this study used a coping and stress framework, similar to (Marjorie Armstrong-Stassen, 2005) and examined i) the impact of layoffs on individuals' psychological and physical well-being, ii) the impact of layoffs on the employees affective commitment, iii) coping strategies used by employees, and iv) job search strategies people are using to find new jobs. While, downsizing is a relatively common change management strategy that has been 
adopted for more than two decades (Gandolfi, 2007), today, the prime impetus of most downsizing efforts is the desire for an immediate reduction of costs and simply survival.

Historically, we have described the purpose of research as a "systematic, formal rigorous and precise process employed to gain solutions to problems and/or to discover and interpret new facts and relationships" (Waltz \& Bausell, 1981, p.1) or a "process of looking for a specific answer to a specific question in an organized objective reliable way" (Payton, 1979, p.4). This research seeks to understand the impact of the current economic challenges facing the country on employees who have been laid off and to understand the deep implications layoffs have on our society.

\section{Rationale for Layoffs}

Given the current economic challenges, layoffs are a natural course of action of organizations. The rationale underlying organizations' decision to downsize is straightforward: by reducing costs, executives hope to improve firm profitability. And yet studies show that the effects of layoffs on organizational performance are mixed at best, often, though not always, failing to produce the desired improvements (e.g., W. Cascio, 2003).

Previous work by Farber and Hallock (2000) used stated "reasons" for layoffs in the Wall Street Journal. Specifically they tried to decompose the change in the share price reaction to job loss announcements from the 1970s through the 1990s into a part that is due to a change in the fraction due to certain "reasons" (e.g. deficient demand versus efficiency) and another part due to changes in share price reactions within reason types. They found that up to one-third of the change in the stock price reaction to job loss announcements is due to a change in the mix of reasons.

For almost all of the organizations experiencing mass layoffs, most will allude to the economic volatility and the lack of demand for their respective products and services.

\section{Impact and Consequences of Layoffs}

Without question, employment fulfills many important functions in the lives of adults and older adolescents (Moore, Grunberg, Greenberg, \& Sikora, 2007). Besides an income, work often provides structure for one's time, social connectedness, feelings of self-worth, and the valued role of "breadwinner" (J.C. Latack, Kinicki, \& Prussia, 1995; F. McKee-Ryan, Song, \& Wanberg, 2005). Thus, losing one's job often entails confronting the losses associated with these secondary benefits. It is not surprising, therefore, that job loss, particularly involuntary job loss, has been found to be stressful, and, on average, to have a negative impact on mental health (J.C. Latack et al., 1995).

\subsection{Well-Being}

Employee well-being is crucial to effective management (Wright, 2006). Research on employee well-being has often sought to characterize key elements in a job or organization that may influence employee reactions (P. Warr, 2006). While we have always researched the impact of employee well-being as a predictor of whether employees decide to stay or leave their jobs or its impact on job satisfaction and job commitment, the well being of laid off employees is of pivotal importance.

Cappelli et al., (1997) found that stress-related illnesses were 50\% higher in the companies that had downsized their workforce compared with those companies that had not undergone downsizing and that reports of employee burnout were more than twice as high at companies that had downsized compared with those that had not downsized.

As cited in (Marjorie Armstrong-Stassen, 2005), other researchers (Ferrie, Shipley, Marmot, Stansfeld, \& Davey Smith, 1998; Nelson, Cooper, \& Jackson, 1995; Vahtera, Kivima"ki, \& Pentti, 1997) have also reported that organizational restructuring and downsizing have negative consequences for survivors' health. The use of escape-type coping strategies to deal with organizational downsizing has been shown to be associated with increased health problems (Torkelson \& Muhonen, 2003). With the high number of individuals being laid off from their jobs and the relative unavailability of similar job openings, people are left without adequate income for extended periods of time, resorting to very different and frequently lower paying jobs, resulting in higher level of stress and more health symptoms.

In addition to the physical implications and health issues, employees will generally abandon their commitment to their former employers given the loss of trust. At stake in the layoffs is the reputation of the employer, inability to attract and retain top quality hires, and maintain established levels of productivity.

Proposition 1A: Individuals will experience significant more health problems after being laid off from their jobs.

Proposition 1B: Individuals who have been unemployed for longer periods will have lower affective commitment to their former employers. 


\subsection{Coping with Layoffs}

"Coping refers to efforts to master conditions that tax or exceed adaptive resources" (Monat \& Lazarus, 1977, p.3). Coping has been found in the survivor literature to be significantly related to survivors' attitudes and behaviors (M Armstrong-Stassen, 1994; Begley, 1998). Armstrong-Stassen (2005) examined six coping strategies: positive-thinking coping, direct-action coping, instrumental support seeking, avoidance, disengagement, and job seeking. These six coping strategies are included in this study as part of the survey instrument and subsequently some of the measures.

There is no doubt that the coping strategies used by different people will have varying results on the job search success and their well being. Coping strategy basically refers to attempts made by individuals to eliminate stress producing factors (Beehr \& Newman, 1978).

Latack's (1986) framework utilized positive-thinking coping where this reflects recasting the situation in positive terms such as thinking of the challenges in the situation. Direct action represents task-focused, problem solving efforts such as devoting more time and energy to one's job. Instrumental support seeking consists of strategies designed to seek information from others. Avoidance coping reflects avoidance of the situation. Job seeking involves actively taking steps to find a job elsewhere.

According to Latack (1986), positive-thinking coping, direct-action coping, and support seeking represent control-oriented coping strategies, whereas avoidance and disengagement are forms of escape coping. Control oriented coping strategies are more likely to be exhibited when situations are viewed as controllable, whereas escape coping is likely to be used in situations in which there is little the individual can do to control the outcome or recurrence of the event (Folkman, 1992).

Prussia, Fugate, and Kinicki (2001) commented on only two studies have considered coping goals following job loss. They explained that, Latack et al. (1995) proposed a theoretical model and contended that coping goals are predictive of two types of coping strategies: control-oriented (i.e., proactive strategies aimed at resolving the situation) and escape-oriented (i.e., avoidance strategies centered on escaping or denying the situation). They further suggested that coping goals explain why individuals pursue different coping strategies when confronted with the same situation. For example, when displaced, some workers establish and pursue the goal of finding another job. This goal presumably necessitates job-search efforts (a control-oriented coping strategy) aimed at reemployment. Other displaced workers may choose to "mellow out" because of the stress and anxiety associated with job loss (an escape-oriented coping strategy).

Knowing that the more positive one stays, the more active one will remain in the job search and continue to utilize control-oriented coping strategies. Given the above-mentioned, we offer the following propositions.

Proposition 2A: Individuals maintaining more control-oriented coping strategies will be more progressive in their job searches and more able to cope with layoffs.

Proposition 2B: Coping strategies are positively related to reemployment.

\subsection{Financial Impact}

There is no secret as to the financial challenges the current wave of layoffs is having on individuals and families across the country. Anecdotal evidence highlights the lifestyle changes people have made, including reduction of savings and the sale of stock and other property by individuals to cope with the loss of their income. Many individuals describe the changes in their earlier lifestyle and a greater impact on their social life as additional consequences of layoffs. Based on media reports, individuals have resorted to selling their real estate, moving into smaller houses, sold stocks, cashed out on retirement savings, took out loans to meet expenses, and filed for bankruptcy.

A construct related to financial resources, but yet distinguishable, is perceived financial strain. Perceived financial strain, sometimes labeled perceived financial hardship, has been examined by asking respondents to indicate how worried they are about their financial situation or how difficult it is to meet expenses (Frances McKee-Ryan, Song, Wanberg, \& Kinicki, 2005). We therefore offer the following propositions.

Proposition 3: Even though individuals are receiving unemployment insurance and other benefits, financial hardships exist resulting in significant challenges and life style changes.

Proposition 3B: Coping strategies are positively related to financial resources available to an individual. 
Although it is generally believed that layoffs are undertaken to benefit investors and that employees bear the brunt of corporate downsizing, there is relatively little empirical research concerning the effect of layoffs on the company's stockholders. Moreover, recent anecdotal evidence suggests that, contrary to common belief, corporate downsizing involving layoffs may not benefit the shareholders (Olive, 1993).

Well-Being. Employee well-being represents the physical, mental, and emotional facets of employee health, synergistically acting to affect individuals in a complex manner (DeJoy \& Wilson, 2003). There is no general agreement on the best indicators of employee well-being, and many types of employee well-being have consequences for the organization. Specifically, theory and research, and as mentioned in (Grawitch, Gottschalk, \& Munz, 2006) have focused on constructs such as general physical health, general mental health, job satisfaction, employee morale, stress, motivation, organizational commitment, and climate (e.g., Goetzel, 2003; Yeung \& Berman, 1997).

One way to assess these people's feelings of subjective well-being is to use their scores from the General Health Questionnaire (GHQ) section of the survey. Argyle (1989) argued that a GHQ assessment is one of the most reliable indicators of psychological distress or 'disutility'.

Coping. Measures of self-esteem and life satisfaction were used as indicators of this construct. Self-esteem was measured with Rosenberg's (1965) 10-item Self-Esteem Inventory.

Job-search effort. Job-search effort also was assessed by using a single-item indicator used by (Prussia et al., 2001). Wanous, Keon, and Latack (1983) and Kinicki (1989) used a similar measure of job-search effort in previous job-loss studies.

Financial Changes. It was critical to determine what financial choices people were making after they had been laid off. So, asking if they had sold their house, used retirement savings, took a loan to pay monthly expenses and other what other choices were being made in trying to survive financially.

Demographic Variables. The demographic variables included age, gender, education, length of time employed by previous company, job level, and industry.

\section{Conclusion}

It is true that the purpose of research is to create new knowledge. This is as real as research gets given the nature of the impact of layoffs on individuals, families and subsequently, communities and as a nation. It is the intent that through our research, individuals and organizations can better understand the consequences and hopefully be able to more effectively manage layoffs and the repercussions of taking these measures. Layoffs do not only have short term effects, but could critically affect the individual laid-off, the entire family, including children. Hopefully, this research can serve as a resource to understanding layoffs from a broader perspective.

\section{References}

Argyle, M. (1989). The Psychology of Happiness. London: Routledge.

Armstrong-Stassen, M. (1994). Coping with transition: A study of layoff survivors. Journal of Organizational Behavior, 15, 597-621. http://dx.doi.org/10.1002/job.4030150705

Armstrong-Stassen, M. (2005). Coping With Downsizing: A Comparison of Executive-Level and Middle Managers. International Journal of Stress Management, 12(2), 117-141. http://dx.doi.org/10.1037/1072-5245.12.2.117

Beehr, T. A., \& Newman, J. E. (1978). Job stress, employee health and organizational effectiveness: a facet analysis, model and literature review. Personnel Psychology, 31, 665-699. http://dx.doi.org/10.1111/j.1744-6570.1978.tb02118.x

Begley, T. M. (1998). Coping strategies as predictors of employee distress and turnover after an organizational consolidation: A longitudinal analysis. Journal of Occupational \& Organizational Psychology, 71, 305-330. http://dx.doi.org/10.1111/j.2044-8325.1998.tb00679.x

Bergin, M., \& Solman, R. (1995). Coping with restructuring: A study of senior educational administrators. Journal of Educational Administration, 33(2), 52-68. http://dx.doi.org/10.1108/09578239510081309

BLS. (2008). Employment Situation Summary. Bureau of Labor Statistics.

Cameron, K. S. (1994). Strategies for Successful Organizational Downsizing. Human Resource Management, 33(2), 189-211. http://dx.doi.org/10.1002/hrm.3930330204 
Cameron, K. S., Freeman, S. J., \& Mishra, A. K. (1991). Best practices in white-collar downsizing: managing contradictions. Academy of Management Executive, 5(3), 57-73.

Cappelli, P., Bassi, L., Katz, H., Knoke, D., Osterman, P., \& Useem, M. (1997). Change at work. New York: Oxford University Press.

Cascio, W. (2003). Managing Human Resources: Productivity, Quality of Work Life, Profits (6th ed.). New York: McGraw-Hill Education.

Cascio, W. F. (2005). Strategies for responsible restructuring. Academy of Management Executive, 19(4), 39-50. http://dx.doi.org/10.5465/AME.2005.19417906

De Meuse, K. P., Bergmann, T. J., Vanderheiden, P. A., \& Roraff, C. E. (2004). New Evidence Regarding Organizational Downsizing and a Firm's Financial Performance: A Long-term Analysis. Journal of Managerial Issues, 16(2), 155-177.

DeJoy, D. M., \& Wilson, M. G. (2003). Organizational health promotion: Broadening the horizon of workplace health promotion. American Journal of Health Promotion, 17, 337-341. http://dx.doi.org/10.4278/0890-1171-17.5.337

DeWitt, R.-L. (1993). The Structural Consequences of Downsizing. Organization Science, 4(1), 30-40. http://dx.doi.org/10.1287/orsc.4.1.30

Folkman, S. (1992). Making the case for coping. In B. N. Carpenter (Ed.), Personal coping: Theory research and application (pp. 31-46). Westport, CT: Praeger.

Gandolfi, F. (2007). How do large Australian and Swiss banks implement downsizing? Journal of Management \&. Organization, (2), 145-159.

Goetzel, R. Z. (2003). Health productivity management: How to maximize the health and productivity of your workforce. LIMRA's MarketFacts Quarterly, 22, 52-55.

Grawitch, M. J., Gottschalk, M., \& Munz, D. C. (2006). The path to a healthy workplace: A critical review linking healthy workplace practices, employee well-being, and organizational improvements. Consulting Psychology Journal: Practice and Research, 58(3), 129-147. http://dx.doi.org/10.1037/1065-9293.58.3.129

Hom, P. W., \& Griffeth, R. W. (1995). Employee turnover. Ohio: South-Western College.

Kammeyer-Mueller, J., \& Liao, H. (2006). Workforce reduction and job-seeker attraction: Examining job seekers' reactions to firm workforce-reduction policies. Human Resource Management, 45(4), 585-603. http://dx.doi.org/10.1002/hrm.20133

Kinicki, A. J. (1989). Predicting occupational role choices after involuntary job loss. Journal of Vocational Behavior, 35, 204-218. http://dx.doi.org/10.1016/0001-8791(89)90041-9

Latack, J. C. (1986). Coping with job stress: Measures and future directions for scale development. Journal of Applied Psychology, 71, 377-385. http://dx.doi.org/10.1037/0021-9010.71.3.377

Latack, J. C., Kinicki, A. J., \& Prussia, G. E. (1995). An integrative process model of coping with job loss. Academy of Management Review, 20, 311-335.

March, J. G., \& Simon, H. A. (1958). Organizations. New York: Wiley.

McKee-Ryan, F., Song, Z., \& Wanberg, C. R. (2005). Psychological and physical wellbeing during unemployment: A meta-analytic study. Journal of Applied Psychology, 90, 53-76. http://dx.doi.org/10.1037/0021-9010.90.1.53

McKee-Ryan, F., Song, Z., Wanberg, C. R., \& Kinicki, A. J. (2005). Psychological and Physical Well-Being During Unemployment: A Meta-Analytic Study. Journal of Applied Psychology, 90(1), 53-76. http://dx.doi.org/10.1037/0021-9010.90.1.53

Mobley, W. H., Griffeth, R. W., Hand, H. H., \& Meglino, B. M. (1979). Review and conceptual analysis of the employee turnover process. Psychological Bulletin, 86, 493-522. http://dx.doi.org/10.1037/0033-2909.86.3.493

Monat, A., \& Lazarus, R. S. (1977). Stress and coping: An anthology. New York: Columbia University Press.

Moore, S., Grunberg, L., Greenberg, E., \& Sikora, P. (2007). Type of Job Loss and its Impact on Decision Control, Mastery, and Depression: Comparison of Employee and Company-Stated Reasons. Current Psychology, 26(2), 71-85. http://dx.doi.org/10.1007/s12144-007-9007-5 
Near, J. P., Rice, R. W., \& Hunt, R. G. (1978). Work and extra-work correlates of life and job satisfaction. Academy of Management Journal, 21, 248-264. http://dx.doi.org/10.2307/255758

Olive, D. (1993). Partially Anticipated Events: A Model of Stock Price Reactions with an Application to Corporate Acquisitions. Journal of Financial Economics, 14, 237-250.

Payton, O. D. (1979). Research: The Validation of Clinical Practice. Philadelphia: F.A. Davis.

Price, J. L. (1977). The study of turnover. Ames: Iowa: State University Press.

Prussia, G. E., Fugate, M., \& Kinicki, A. J. (2001). Explication of the Coping Goal Construct: Implications for Coping and Reemployment. Journal of Applied Psychology, 86(6), 1179-1190. http://dx.doi.org/10.1037/0021-9010.86.6.1179

Schwartz, J. E., \& Stone, A. A. (1993). Coping with daily work problems: Contributions of problem content, appraisals, and person factors. Work \& Stress, 7, 47-62. http://dx.doi.org/10.1080/02678379308257049

Sevastns, P., Smith, L., \& Cordery, J. L. (1992). Evidence on the reliability and construct validity of Warr's (1990) well-being and mental health measures. Journal of Occupational and Organizational Psychology, 65, 33-39. http://dx.doi.org/10.1111/j.2044-8325.1992.tb00482.x

Waltz, C., \& Bausell, R. (1981). Nursing research: design, statistics and computer analysis. Philadelphia: FA Davis.

Wang-Bae, K. (2003). Economic Crisis, Downsizing and "Layoff Survivor's Syndrome. Journal of Contemporary Asia, (33).

Wanous, J. P., Keon, T. L., \& Latack, J. C. (1983). Expectancy theory and occupational/organizational choices: A review and test. Organizational Behavior and Human Decision Processes, 32, 66-86. http://dx.doi.org/10.1016/0030-5073(83)90140-X

Warr, P. (2006). Differential activation of judgments in employee well-being. Journal of Occupational \& Organizational Psychology, 79(2), 225-244. http://dx.doi.org/10.1348/096317905X52652

Warr, P. B. (1990). The measurement of well-being and other aspects of mental health. Journal of Occupational Psychology, 63, 193-210. http://dx.doi.org/10.1111/j.2044-8325.1990.tb00521.x

Warr, P. B. (1994). Age and employment. In H. C. Triandis, M. D. Dunnette \& L. M. Hough (Eds.), Handbook of industrial and organizational psychology (Vol. 4, pp. 485-550). Alto, CA: Consulting Psychologists Press.

Wright, T. A. (2006). To Be Or Not To Be [Happy]: The Role of Employee Well-Being. Academy of Management Perspectives, 20(3), 118-120. http://dx.doi.org/10.5465/AMP.2006.21903486

Yeung, A. K., \& Berman, B. (1997). Adding value through human resources: Reorienting human resource measurement to drive business performance. Human Resource Management, 36, 321-335. http://dx.doi.org/10.1002/(SICI)1099-050X(199723)36:3<321::AID-HRM4>3.0.CO;2-Y

Zatzick, C. D., \& Iverson, R. D. (2006). High-involvement Management and Workforce Reduction: Competitive Advantage or Disadvantage? Academy of Management Journal, 49(5), 999-1015. http://dx.doi.org/10.5465/AMJ.2006.22798180 